\title{
ANALYSIS OF THE AGRI-BUSINESS SECTOR AS A POTENTIAL AND SUSTAINABILITY SECTOR IN FOOD SECURITY
}

\author{
Patiung Markus*, Susilo Achmadi, Ernawati \\ Master's Study Program of Agribusiness, Faculty of Agriculture, Wijaya Kusuma University, \\ Indonesia \\ *E-mail: markuspatiung@uwks.ac.id
}

\begin{abstract}
Indonesia has the potential for natural resources, namely forestry, plantations, livestock, fisheries and food crops (agribusiness sector), which is why Indonesia is known as an agricultural country. This agribusiness sector in the abbreviated Gross Regional Domestic Product (agriculture, forestry and fisheries sectors). This potential must be managed properly by the Indonesian government and its people so that the people are prosperous and prosperous. The potential that the Indonesian nation possesses as a gift from God has suffered a lot of damage and conversion. The research objectives were (1) to analyze the agribusiness sector as a potential and sustainable sector or not, (2) to analyze whether the agribusiness sector could create food security and prosper the people of Bojonegoro and the Indonesian nation in general. The analytical methods used are Location Quotient (LQ), Dynamic Location Quotient (DLQ), LQ and DLQ comparison, and Klassen Typology. The research location is in Bojonegoro district. The results of the research with an $L Q$ analysis of 1.90 means that the products of the agribusiness sector are a potential sector, surplus and can be exported to other regions and can even be exported to foreign countries. The DLQ result of 1.16 means that the agribusiness sector is a sector that is growing faster than the same sector in the surrounding area or in the province of East Java. The comparison between $L Q$ and DLQ shows that $L Q<1$ and $D L Q>1$ shows that the agribusiness sector is a leading sector, which means that it will remain a potential sector both now and in the future (agribusiness sector is a sustainable sector). The pattern of economic growth through Klasen typology analysis shows that this rik <ri and yik> yi shows that the agribusiness sector is an advanced and slow-growing sector. Overall, the agribusiness sector in Bojonegoro district can make people prosperous.
\end{abstract}

\section{KEY WORDS}

Sector, analysis, welfare, agribusiness.

Indonesia has the potential of natural resources, namely forestry, plantations, animal husbandry, fisheries and food crops (agribusiness sector) as a gift from God. And this potential must be managed and developed properly by the government so that the people are prosperous and prosperous(Huda, Miftakhul; Santoso 2014);(Starch 2018). In Macedonia, agribusiness is one of the most promising sectors in the Macedonian economy, considering the average share of agribusiness in GDP is $10 \%$ and accounts for $17.87 \%$ of total employment(Ciglovska 2018), in Russia the country's potential shows a transition to economic growth, namely emphasizing the use of modern technology (Babaev, Nikolaeva, and Babaev 2019). On the other hand, Sziemai's research said that several countries in the world experienced growth from the manufacturing sector, and manufacturing productivity was higher than the agribusiness sector, manufacturing had a higher productivity growth rate than other sectors.(Szirmai 2012). In ASEAN countries Agribusiness is an important sector, in Indonesia the largest agribusiness sector generates Gross Domestic Product after the Industrial sector where the agribusiness sector contributes $13.41 \%$, Industry $21.31 \%$, trade 13.37, mining $11.05 \%$ and others 40 , 85\%(New Guinea et al. 2019), Indonesia has extraordinary natural resource potential so that Indonesia is known as an agrarian / agribusiness country. Even Indonesia as an agricultural country is expected to be able to become one of the world's food providers. 
According to experts or experts, when a country manages beyond its potential, that is where the country falls into poverty. Because managing a country beyond its potential will require high costs, because it does not have raw materials and skilled personnel, so that the resulting product is difficult to compete in the international market or with other countries. If a country does not plan well, it will experience failure, this can be seen from the results of research by Nong (2019) which show that the Philippines, Thailand, Malaysia, Indonesia, Ecuador and Peru have had quite a large negative impact on the economy, food industry, and household. Vietnam is experiencing an economic downturn due to poorly managed marine fish resources,

The most appropriate way to develop the national economy of a country so that its people are prosperous is to develop economic activities on which the economic life of most of its people is based. Indonesia (60-70\%) of the population lives in the agribusiness sector. Therefore, the agribusiness sector must become the yardstick / backbone of the national economy. For this reason, the industrialization strategy that must be developed is the agricultural industry strategy in the form of agribusiness development.

Most of the potential is damaged due to the government's lack of concern for its potential. One example, for example, Indonesia's forests have been damaged and have never been reforested. Too many productive lands have been converted into non-agricultural land (almost 1 million ha / year). The government's policy towards agribusiness is very low, it is proven that agribusiness is not the main choice in development, so it is difficult to develop in the context of the welfare of its people, let alone to become a world food provider. Therefore, this research tries to analyze whether the agribusiness sector as one of the economic sectors that can contribute to the Gross Regional Domestic Product is a sustainable sector or not.

Goal of research is to (1) analyze the agribusiness sector as a potential and sustainable sector or not, (2) to analyze whether the agribusiness sector can create food security and prosper the people of Bojonegoro and the Indonesian nation in general.

\section{LITERATURE REVIEW}

The agricultural sector is still the main contributor to most districts in Indonesia, both in the formation of GRDP (gross regional domestic product), job and business opportunities, as well as regional exports. With the implementation of the Regional Autonomy program, districts / cities have broader authority in developing an economic system in accordance with the conditions and situations of their respective regions. Considering that agriculture is still a basic sector in most regions, agricultural activity is the most ready and suitable business to be used in the current acceleration of economic development. Agribusiness modernization in the regions will have a significant impact on regional economic growth and can be used as a solution in dealing with regional economic problems.

Forests are a producer of wood and a producer of environmental products / services as competition. This means that if the forest is left unchecked it will become a product and provide environmental services, and if it is cut down it will generate foreign exchange from timber and other forest products. Thus, it must be realized that forest resources have limited carrying capacity and utilization, even though they are renewable resources.

A very potential source of income that has not been developed domestically is the exploitation of environmental services produced by forests. These environmental services can be classified into environmental services that are global in nature and those that are local in nature. What is global in nature is the nature of forests that can capture carbon (carbon sequestration) produced from various industries, both in Indonesia and in developed industrial countries. Industries in developed countries have produced excessive amounts of carbon emissions, causing a green house effect that could endanger the continuity of life in the world. Indonesia by protecting forests will improve the function of forests as the lungs of the world.

The development of the fisheries sector needs to be directed towards increasing its role in creating linkages with other sectors through increasing added value, absorption of 
labor and increasing income, as well as strong linkages with other sectors both forward and backward linkages, which in turn will foster activities. economy.

The fast and impressive economic progress before the economic crisis, the Indonesian agricultural sector which was driven by the activities of small-scale farmers (smallholders) and fishermen was able to support overall economic growth through strong backward and backward linkages as well as through the growth in demand created by the agricultural sector (demand creation from agriculture).

Food security is the availability of food and a person's ability to access it. a household is said to have food security if the occupants are not in a state of hunger or threat.

Food security is a measure of resilience to future disruptions or the absence of essential food supplies due to various factors such as: drought, shipping disruption, fuel scarcity, economic instability, war, and so on. The food security assessment is divided into self-sufficiency or individual self-sufficiency (self-sufficiency) and external dependence which divides a series of risk factors.

Although various countries are eager for individual self-sufficiency to avoid the risk of transportation failure, this is difficult to achieve in developed countries because of the highly diverse social profession and the high cost of producing foodstuffs if it is not industrialized. On the other hand, high individual self-sufficiency without an adequate economy will make a country vulnerable to production.

The World Health Organization defines three main components of food security, namely food availability, food access and food utilization. Availability of food is the ability to have a sufficient amount of food for basic needs. Food availability is the ability to have a number of resources, both economically and physically, to obtain nutritious food. Utilization of food is the ability to use food ingredients correctly and appropriately proportionally. FAO added a fourth component, namely the stability of the three components over a long period of time.

Gross regional domestic product is the amount of gross added value arising from all economic sectors in the region. Calculating GRDP aims to help formulate regional policies or plans, evaluate development results, provide information that can describe regional economic performance.

GRDP can be used as an indicator of the rate of sectoral economic growth so that it can be seen which sectors are causing changes in economic growth. The GRDP calculation uses two types of prices, namely GRDP at current prices and GRDP at constant prices. GRDP at current prices illustrates the added value of goods and services calculated using the prevailing price each year by taking into account the inflationary element and can be used to see economic shifts and structure, while GRDP at constant prices shows the added value of these goods and services that use them. The price is valid in a certain year as a basis and can be used to determine economic growth from year to year without taking into account the element of inflation.

PDRB data is very important information to determine output in the economic sector and to see growth in a certain area (Province / Regency / City). With the help of GRDP data, it is possible to determine the leading sector in an area / region. A leading sector is a sector / sub-sector capable of encouraging economic activity and creating prosperity in an area, especially through production, export and job creation, so that the identification of leading sectors is very important, especially in determining priorities and planning for regional economic development. The higher the GRDP per capita value, the higher the region's prosperity, in other words, the per capita GRDP value is considered to reflect the level of regional wealth (Tadjoedin, Suharyo, \& S, 2001).

\section{METHODS OF RESEARCH}

This research was conducted in Bojonegoro Regency, East Java Province, Indonesia, with the consideration that Bojonegoro Regency is a district with agribusiness potential. The data used in this study are secondary data, namely data on the Gross Regional Domestic 
Product of Bojonegoro Regency and the Gross Regional Domestic Product of East Java Province for the last five years (2015 - 2019).

The analytical methods used are Location Quotient (LQ), Dynamic Location Quotient (DLQ) and Klassen Typology. The Location Quotient (LQ) analysis method is used to determine whether the agribusiness sector is a base / potential sector or a non-basis / nonpotential sector. While the Dynamic Location Quotient (DLQ) analysis method is used to determine the agribusiness sector in Bojonegoro Regency is growing faster or slower than the same sector in the scope of regional domestic products in East Java Province. The comparison of $L Q$ and DLQ results can determine whether the agribusiness sector is included in a leading sector, or a prospective sector, or a mainstay sector or a lagging sector. Klassen typology analysis method is used to determine whether the agribusiness sector is a fast-growing and fast-growing sector.

Meanwhile, the LQ calculation formula used in this study is (Budiharsono 2001):

$$
\mathrm{LQ}=\frac{\mathrm{V} 1 \mathrm{R} / \mathrm{VR}}{\mathrm{V} 1 / \mathrm{V}}
$$

Where: V1R: The value of the agribusiness sector on the district's gross regional domestic product of Bojonegoro; VR: The value of all sectors in the district's gross regional domestic product of Bojonegoro; V1: The value of the agribusiness sector on the gross regional domestic product of East Java Province; V: The value of all sectors in the gross regional domestic product of East Java Province.

Based on the location quotient (LQ) analysis, if the value of $L Q>1$ then the agribusiness sector is a potential / base sector, meaning that the production of the agribusiness sector (agriculture, forestry and fisheries) produced can not only meet the needs in Bojonegoro district but can be exported to other regions. or abroad, this shows that food security is steady. The higher the LQ value than one, the higher the comparative advantage(Cahyono, S Andy and Wijaya 2014). Conversely, if the value of $L Q<1$, then the agribusiness sector is classified as a non-base sector, has no advantages / non-potential, the production of this sector cannot meet its own needs so it needs supplies or imports from outside Bojonegoro district, which shows that it is difficult to achieve food security. If the value of $L Q=1$, the agribusiness sector is classified as having no advantages, production from the agribusiness sector is only able to meet the needs of Bojonegoro district and cannot be exported to other regions or abroad.

Economic changes in Bojonegoro district during a certain period of time can be tested through one of the analytical tools, namely the Dynamic Location Quotient (DLQ) so that sectoral changes can be identified. DLQ is a modified form of LQ by accommodating the amount of gross regional domestic product from the production value of each sector from time to time. The ups and downs of the DLQ can be seen for certain sectors at different time dimensions with the following formulation(Nazipati 2007):

$$
\begin{gathered}
\text { DLQ ij }=\text { - }(1+\mathrm{gij}) /(1+\mathrm{gj}) \\
(1+\mathrm{Gi}) /(1+\mathrm{G})
\end{gathered}
$$

Where: DLQij: The potential index of the agribusiness sector on gross regional domestic product ofBojonegoro district; gij: The rate of added value growth in the agribusiness sector in domestic products regional gross of Bojonegoro Regency; gj: The district's average gross regional domestic product growth rate of Bojonegoro; Gi: The rate of added value growth in the agribusiness sector in domestic products of East Java Province gross; G.: Average growth in the gross regional domestic product of East Java Province.

If the DLQ value is more than 1, then the potential development of the agribusiness sector (agriculture, forestry and fisheries) in Bojonegoro district's gross regional domestic 
product is faster than the same sector within the scope of the East Java Province gross regional domestic product. Conversely, if the DLQ $<1$, then the potential development of the agribusiness sector (agriculture, forestry and fisheries) in the regional gross domestic product of Bojonegoro Regency is lower than the overall gross regional domestic product in East Java Province.

The comparison between LQ and DLQ values can be used as a criterion in determining whether the agribusiness sector (agriculture, forestry and fisheries) is classified as a leading sector, or a prospective sector, or a mainstay sector, or a lagging sector. The criteria are as follows(Suyatno 2007):

a. If $L Q$ and $D L Q$ values> 1 , the agribusiness sector is a leading sector, meaning that the agribusiness sector (agriculture, forestry and fisheries) will remain the basis for both present and future;

b. If the value of $L Q>1$ and $D L Q<1$, the agribusiness sector is a prospective sector, meaning that the agribusiness sector (agriculture, forestry and fisheries) will shift from the current base sector to the non-base sector in the future;

c. If the value of $L Q<1$ and $D L Q>1$, the agribusiness sector is the mainstay sector, meaning that the agribusiness sector (agriculture, forestry and fisheries) will shift from the current non-base sector to the basic sector in the future.

d. If the value of $L Q$ and $D L Q<1$, the agribusiness sector is an underdeveloped sector, meaning that the agribusiness sector (agriculture, forestry and fisheries) will continue to be a non-basis both now and in the future.
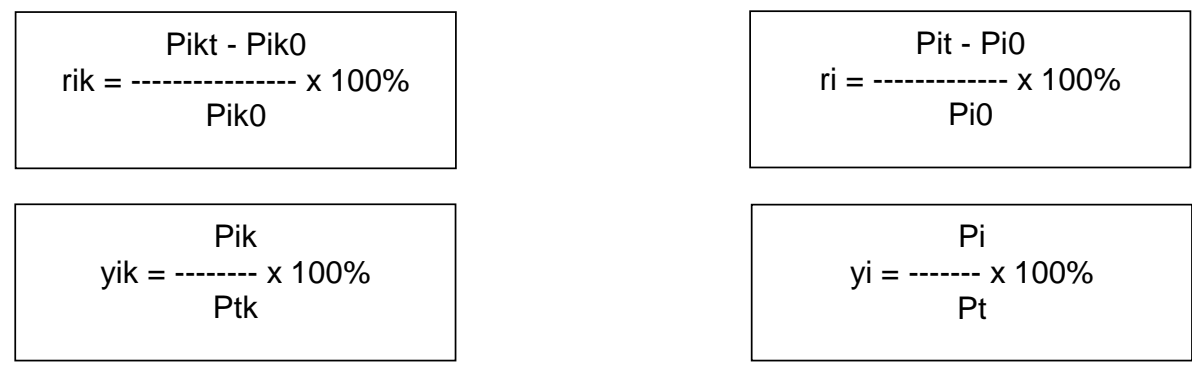

Where: rik = The rate of growth in the production value of the agribusiness sector in domestic products regional gross of Bojonegoro Regency; ri = The rate of growth in the production value of the agribusiness sector in domestic products regional gross of East Java Province; yik = The contribution of the agribusiness sector to the total production value of the product regional gross domestic product of Bojonegoro Regency; yi = The contribution of the agribusiness sector to the total production value of the product Gross Regional Domestic Product of East Java Province; Pikt = The production value of the agribusiness sector in gross regional domestic product of East Java Province year $\mathrm{t}$; Piko $=$ The production value of the agribusiness sector in gross regional domestic product of Bojonegoro Regency early years $(\mathrm{t}-1)$; $\mathrm{Pit}=$ The production value of the agribusiness sector in gross regional domestic of product East Java Province year $\mathrm{t}$; $\mathrm{Pio}=$ The production value of the agribusiness sector in the gross regional domestic product of East Java Province early years (t-1); $\mathrm{Pik}=$ The production value of the agribusiness sector in gross regional domestic product of Bojonegoro Regency; Ptk = The total production value of the district's gross regional domestic product of Bojonegoro; $\mathrm{Pi}=$ The production value of the agribusiness sector in gross regional domestic product of East Java; $\mathrm{Pt}=$ total production value in the gross regional domestic product of East Java Province.

Table 1 - Typology of Sector Growth according to Klassen

\begin{tabular}{|l|l|l|}
\hline $\mathrm{n} / \mathrm{n}$ & Yik $>$ yi & Yik <yi \\
\hline Rik $>$ ri & The sector is developed and growing fast & Fast growing sector \\
\hline Rik $<$ ri & Developed and slow growing sectors & The sector is relatively underdeveloped \\
\hline
\end{tabular}

Source: Sjafrizal, 2008. 
Note for Table 1: rik = The rate of growth in the production value of the agribusiness sector (agriculture, forestry and fisheries) on the gross regional domestic product of Bojonegoro Regency; $r i$ = The rate of growth in the production value of the agribusiness sector (agriculture, forestry and fisheries) in the gross regional domestic product of East Java Province; yik = The contribution of the agribusiness sector (agriculture, forestry and fisheries) to total gross regional domestic product production value of Bojonegoro Regency; $y i=$ Contribution of the agribusiness sector (agriculture, forestry and fisheries) to total gross regional domestic product production value of East Java Province.

\section{RESULTS AND DISCUSSION}

The results showed that the value of $L Q=1.90$, this indicates that the agribusiness sector in Bojonegoro district is a potential sector, meaning that the agribusiness sector in Bojonegoro district is not only able to meet the needs of the people of Bojonegoro district, but its agribusiness products are surplurable so that it can be exported to other areas in the region, country or exported to foreign countries. The results of the LQ calculation are as in table 2.

Table 2 - Calculation of LQ Bojonegoro Regency

\begin{tabular}{|c|c|c|c|c|c|c|c|c|}
\hline Business field & Year & V1r & VR & V1 & V & V1r/VR & V1/V & LQ \\
\hline \multirow{6}{*}{$\begin{array}{l}\text { Agriculture, Forestry and } \\
\text { Fisheries (agribusiness sector) }\end{array}$} & 2015 & $8,399.20$ & $48,606.70$ & $230,942.46$ & $1,691,477.06$ & 0.17 & 0.14 & 1.27 \\
\hline & 2016 & $9,012.30$ & $55,581.40$ & $249,453.63$ & $1,855,738.43$ & 0.16 & 0.13 & 1.21 \\
\hline & 2017 & $9,361.10$ & $64,866.20$ & $258,454.42$ & $2,012,917.99$ & 0.14 & 0.13 & 1.12 \\
\hline & 2018 & $9,604.60$ & $73,232.30$ & $260,513.83$ & $2,189,823.64$ & 0.13 & 0.12 & 1.10 \\
\hline & 2019 & $9,819.90$ & $78,047.20$ & $268,772.16$ & $2,352,425.22$ & 0.13 & 0.11 & 1.10 \\
\hline & \multicolumn{7}{|c|}{ Amount } & 1.16 \\
\hline
\end{tabular}

Source: Data Analysis, 2015-2019.

The results of the study using DLQ analysis showed a result of 1.16, meaning that the agribusiness sector is a sector whose development / growth is faster than the same sector in the surrounding area or in the region in East Java Province. The DLQ calculation results are shown in Table 3.

Table 3 - Calculation of DLQ Bojonegoro Regency

\begin{tabular}{|c|c|c|c|c|c|c|c|c|}
\hline Business Income & Year & gij & gj & $\mathrm{Gi}$ & G. & $(g i j / g j)$ & $(\mathrm{Gi} / \mathrm{G})$ & DLQ \\
\hline \multirow{6}{*}{$\begin{array}{l}\text { Agriculture, Forestry and Fisheries (agribusiness } \\
\text { sector) }\end{array}$} & 2015 & 3.25 & 7.38 & 3.38 & 5.30 & 0.44 & 0.64 & 0.69 \\
\hline & 2016 & 2.89 & 7.76 & 2.99 & 5.64 & 0.37 & 0.53 & 0.70 \\
\hline & 2017 & 0.90 & 6.60 & 1.19 & 5.37 & 0.14 & 0.22 & 0.61 \\
\hline & 2018 & -1.00 & 6.36 & -0.12 & 5.36 & -0.16 & -0.02 & 7,19 \\
\hline & 2019 & 0.22 & 5.94 & 0.63 & 5.08 & 0.04 & 0.12 & 0.30 \\
\hline & \multicolumn{7}{|c|}{ Amount } & 1.90 \\
\hline
\end{tabular}

Source: Data Analysis, 2015-2019.

The results of the comparative analysis between $L Q$ and $D L Q$ show that $L Q<1$ and DLQ> 1 , so that the agribusiness sector is a leading sector, which means that the agribusiness sector is currently a potential sector and will continue to be a potential sector in the future. This shows that the agribusiness sector is a sustainable sector. The results of the LQ and DLQ comparisons are as shown in Table 4.

Table 4 - Comparison Results of LQ and DLQ in Bojonegoro Regency

\begin{tabular}{|l|l|l|l|}
\hline Business field & LQ & DLQ & Criteria \\
\hline Agriculture, Forestry and Fisheries (agribusiness sector) & 1.16 & 1.90 & Leading Sector \\
\hline
\end{tabular}

Source: Data Analysis, 2015-2019.

The results of the analysis show that $L Q>1$ means that the products of the agribusiness sector in Bojonegoro district have a surplus, which means that the agribusiness sector can not only meet the food needs of the people of Bojonegoro district, but can also be exported to other regions in the country or exported to foreign countries. This shows the existence of food security in Bojonegoro district. On the other hand, the pattern of economic 
growth in Bojonegoro Regency through the analysis of Klassen typology shows that rik <ri and yik> yi, which means that the agribusiness sector is an advanced sector but its growth is slow. The agribusiness sector, which is an advanced sector but with slow growth, can be overcome by a number of things, for example returning the agribusiness sector to become the main sector in national development planning. Maintaining fertile natural resources such as paddy fields, agricultural land is not converted into non-agricultural land; agricultural sector funding is the main thing because it is the potential of the Indonesian nation. The calculation of class typology is as shown in Table 5.

Table 5 - Classification Typology Analysis

\begin{tabular}{|l|l|l|l|l|l|l|l|}
\hline Business field & rik & ri & $\begin{array}{l}\text { Growth } \\
\text { rate }\end{array}$ & yik & yi & Contribution & Criteria \\
\hline $\begin{array}{l}\text { Agriculture, Forestry, Fishery } \\
\text { Sector (agribusiness sector) }\end{array}$ & 1.25 & 1.61 & rik $<$ ri & 0.144 & 0.126 & yik> yi & $\begin{array}{l}\text { Advanced and Slow } \\
\text { Growing Sectors }\end{array}$ \\
\hline
\end{tabular}

Source: Data Analysis, 2015-2019.

Therefore, the Bojonegoro district government should pay attention to the agribusiness sector both in terms of maintaining its natural resources and the funding sector. If so far the agribusiness sector is considered not as the main sector, then the agribusiness sector should now be the main sector in development planning. The conversion of fertile agricultural land to the non-agricultural sector was immediately stopped. If nationally the land conversion from the agricultural sector to the non-agricultural sector amounts to 1 million ha per year, then Bojonegoro district contributes how much to the national land conversion each year. The hope is that Bojonegoro district will not convert fertile agricultural land to the non-agricultural sector because the agribusiness sector in Bojonegoro district is a potential and sustainable sector.

Of the 17 sectors that contribute to the PDRB of Bojonegoro Regency, the sectors classified as potential sectors are (1) agriculture, forestry and fisheries (agribusiness sector); (2) mining and quarrying sector; (3) information and communication sector, (4) mandatory government administration, defense and social security sector; while the other 13 sectors are not potential sectors.

Only agriculture, forestry and fisheries (agribusiness sector) are the only sectors that have experienced growth or development that is faster than similar sectors in the surrounding area or in the region within East Java, while the other 16 sectors are sectors that are slow in growth compared to sectors that are the same in the surrounding area or within the province of East Java.

On the other hand, the agricultural, forestry and fisheries sectors (agribusiness sector) are the only sectors of the 17 sectors that contribute to GRDP in Bojonegoro district which are the leading sectors; the only prospective sectors are mining and quarrying; information and communication sector; and mandatory government administration, defense and social security sectors; the remaining 13 sectors are lagging sectors.

On the other hand, the structure and pattern of economic growth in Bojonegoro regency where the growth rate (rik <ri) and its contribution (yik> yi) indicate that the agribusiness sector is an advanced sector and is growing slowly. The sectors that are progressing fast and growing slowly are the information and communication sector; while the fast growing sectors are mining and quarrying; wholesale and retail trade, car and motorcycle repair; transportation and storage sector; the sector of providing accommodation and food and drink; the financial services and insurance sector; real estate sector; corporate service sector; while other sectors are relatively lagging behind.

Based on the analysis above, it shows that the agribusiness sector in Bojonedoro district is a potential and sustainable sector. Besides that, the agribusiness sector is a sector that can prosper the people of Bojonegoro and people outside Bojonegoro or the world community in terms of food supply. 


\section{CONCLUSION}

In order for the agribusiness sector to be maintained as a potential and sustainable sector, the government must return the agribusiness sector as the main sector in national development planning.

In order for the agribusiness sector to grow rapidly, funding for the agribusiness sector must be equated with the education and health sectors; agribusiness sector infrastructure must be fulfilled, agricultural extension workers must be returned to their original function, the production facilities are fulfilled and the development of the agricultural industry.

\section{REFERENCES}

1. Babaev, Bronislav D, Elena E Nikolaeva, and Dmitry B Babaev. 2019. "The Economic Development Potential of the Country with a Look to the Future." Proceedings of the 2nd International Conference on Economy, Management and Entrepreneurship (ICOEME 2019).

2. Barbier, Edward B. 1987. "The Concept of Sustainable Economic Development." Environmental Conservation 14 (2): 101-10.

3. Berekaa, Mahmoud M. 2015. "Review Article Nanotechnology in Food Industry." Int.J.Curr.Microbiol.App.Sci 4 (5): 345-57.

4. Bogoviz, Aleksei. 2019. "Transforming the Agricultural Sector for Better Sustainable Development: Perspectives from Russia as a Member State of the Eurasian Economic Union." IOP Conference Series: Earth and Environmental Science 274 (1): 0-5.

5. Budiharsono, S. 2001. Coastal and Ocean Development Analysis Techniques. Pradnya Paramita.

6. Cahyono, S Andy and Wijaya, Wahyu Wisnu. 2014. "Inter-Regency Income in the Upper Bengawan Solo Sub-Watershed (Identification of the Leading Economic Sectors and Income Disparity among Regencies in Upper Bengawan Solo Sub Watershed)." Journal of Forestry Social and Economic Research 11 (1): 32-43.

7. Ciglovska, Biljana. 2018. "Developing Sustainable Agricultural Sector, as an Impetus for Macedonia`s Economic Growth." European Journal of Sustainable Development 7 (4).

8. Huda, Miftakhul; Santoso, Eko Budi. 2014. "Development of Regional Competitiveness of Regencies / Cities in East Java Province." Pomits Technical Journal 3 (2): 81-86.

9. Joshua, John. 2017. II China's Economic Growth: Towards Sustainable Economic Development and Social Justice: Volume II: The Impact of Economic Policies on the Quality of Life China's Economic Growth: Towards Sustainable Economic Development and Social Justice: Volume II: The Impact of Economic Policies on the Quality of Life.

10. Mohammed, Habiba I., Z. Majid, and Yamusa B. Yamusa. 2019. "GIS Based Sanitary Landfill Suitability Analysis for Sustainable Solid Waste Disposal." IOP Conference Series: Earth and Environmental Science 220 (1).

11. Nazipati. 2007. "Application of Static and Dynamic Location Quotients and Shift-Share Models in Regional Economic Planning (Case Study of Ogan Komering Ulu Regency, South Sumatra Province)." Eco-Regional 2.

12. Nong, Duy. 2019. "Potential Economic Impacts of Global Wild Catch Fishery Decline in Southeast Asia and South America." Economic Analysis and Policy 62: 213-26.

13. Nugrahini, Wisnujati et al. 2019. "Effort toward the Sustainable Agricultural Development within the Territory the ASEAN." International Journal of Engineering and Advanced Technology.

14. Paper, Conference. 2016. "Gis Based Multi-Criteria Decision Analysis of BioPhysiochemical Parameters for Agricultural Land Suitability Evaluation in Kallar Watershed, Part of Bhavani Basin, Tamil Nadu." (April).

15. Postgraduate, School. 2019. "Planning for Sustainable Agricultural Village Development Based on Drone Image (Case Study of Sukadamai Village, Bogor Regency) Ihsan Arham." (April).

16. Starch, Mark. 2018. "Preparation of the 2017 Markus Agropolitan Area Development 
Master Plan for Probolinggo Regency." Journal of Socio-Agribusiness 18.

17. Quin, Emparan. 2019. "Role of Phycoremediation for Nutrients Removal." Applied Ecology \& Environmental Research 17 (1): 1247-60.

18. Sudaryanto, Tahlim et al. 2018. "Levels of Domestic Support for the Indonesian Agricultural Sector." Agricultural Policy Analysis 14 (1): 73.

19. Suyatno, Suyatno. 2007. "Economic Base Analysis of Regional Economic Growth Level li Wonogiri: Facing the Implementation of Law No. 22/1999 And Uu No. 5/1999. " Journal of Development Economics: Study of Economic and Development Problems 1 (2): 144.

20. Szirmai, Adam. 2012. "Industrialization as an Engine of Growth in Developing Countries, 1950-2005." Structural Change and Economic Dynamics 23 (4): 406-20. 